\title{
Evaluation of Graft-Transmissible Isolates from Dwarfed Citrus Trees as Dwarfing Agents
}

S. P. van Vuuren, Agricultural Research Council-Institute for Tropical and Subtropical Crops, Private Bag X11208, Nelspruit 1200, South Africa; and J. V. da Graça, Department of Microbiology and Plant Pathology, University of Natal, Private Bag X01, Scottsville, Pietermaritzburg 3209, South Africa

\begin{abstract}
van Vuuren, S. P., and da Graça, J. V. 2000. Evaluation of graft-transmissible isolates from dwarfed citrus trees as dwarfing agents. Plant Dis. 84:239-242.

The dwarfing characteristics of four isolates (CD 4, CD 8, CD 9, and CD 10), derived from healthy-looking dwarfed field citrus trees, were evaluated. Each was bud inoculated to cv. Delta Valencia trees on $\mathrm{cv}$. Yuma citrange rootstock prior to planting in the field. At 5 years after planting, isolates CD 4 and CD 9 reduced canopy volumes by $60 \%$, and CD 10 by $30 \%$, without any detrimental effects. No citrus viroids (CVds) were detected biologically or by sequential polyacrylamide gel electrophoresis in these three isolates. Isolate $\mathrm{CD} 8$, however, contained two viroids, citrus exocortis viroid and a Group-III CVd, but had no deleterious effects on the Yuma citrange rootstock. Citrus tristeza virus (CTV) was the only other pathogen detected in all of the isolates. Indexing for cachexia, psorosis, impietratura, and tatter leaf were negative. The dwarfing abilities of the isolates are therefore attributed to CTV. Fruit yield was according to tree size and the yield efficiency of the inoculated trees was equal to that of the uninoculated control trees. External and internal fruit quality was not affected. The trees became naturally infected with huanglongbing (greening) 5 years after planting, but the disease incidence remained low for several years in trees with isolate CD 4.
\end{abstract}

Additional keywords: Citrus tristeza virus, citrus viroids, high-density plantings

High-density planting of citrus has several advantages, but it is important to control tree size $(4,5,13,43,44)$. There are three main methods of tree-size control: genetic, by management, and pathological (30). Each method has its own advantages and disadvantages. However, in the absence of a proven dwarfing rootstock (23), the adverse effects which management practices have on yield (5) and infection by disease (3) make the use of transmissible agents desirable (7). Known agents that have a dwarfing effect on certain citrus cultivars are citrus exocortis viroid (CEVd; $8)$, citrus cachexia viroid $(\mathrm{CcaVd} ; 28)$, other groups of citrus viroids (CVds; 21,34,35), and Citrus tristeza virus (CTV; 10,37). The dwarfing symptom of citrus on Poncirus trifoliata rootstock has been attributed to the exocortis viroid $(15,17,18)$; however, subsequently, a CEVd isolate has been identified in lemon which was not dwarfed (21). Many investigations regarding exocortis dwarfing were done with isolates identified as severe or mild exocortis in accordance with the reaction of

Corresponding author: S. P. van Vuuren

E-mail: fanie@itsc.agric.za

Accepted for publication 10 November 1999.

Publication no. D-2000-0118-02R

(c) 2000 The American Phytopathological Society the etrog citron (Citrus medica L.) indicator. However, when sequential polyacrylamide gel electrophoresis (sPAGE) was developed to identify citrus viroids (16), most of the isolates turned out to be mixtures of different citrus viroids $(12,25$, $28,29,33,34)$. Some of the isolates induced dwarfing without the scaling symptom of the trifoliate rootstock $(11,18,36)$.

Dwarfed trees occur in many citrus orchards in South Africa. Some of these trees are on $P$. trifoliata or trifoliate hybrid rootstocks, which are sensitive to citrus viroid infection, but display no bark scaling symptoms. Similar trees occurred in Australia, from which dwarfing isolates have been selected (7). The objective of this study was to identify transmissible dwarfing agents that could be used to control tree size in high-density plantings in southern Africa.

\section{MATERIALS AND METHODS}

Isolates. Isolates were collected from dwarfed orchard trees and established in the greenhouse on virus-free rough lemon rootstocks. Four isolates, derived from different sources that did not display detrimental disease symptoms, were selected for this investigation (Table 1).

Transmission of dwarfing characteristics. Virus-free cv. Delta Valencia trees on cv. Yuma citrange rootstock were grown according to normal practices under insectfree conditions in a greenhouse. When the scions had developed to approximately 30 $\mathrm{cm}$, they were inoculated with infected buds of isolates CD 4, CD 8, CD 9, or CD 10. After 3 months to allow for the plants to become infected, they were planted in an orchard in a randomized block design with five replications.

Tree-canopy measurements were made annually (9). Each year, all fruit were harvested and weighed. Internal and external fruit quality was determined according to South African export standards (2). The trees were inspected for the development of CTV (stem pitting, decline), viroid (bark scaling, gum pocket), and huanglongbing (greening) symptoms.

Identification of transmissible agents. Biological indexing. The isolates were indexed biologically for the presence of CTV on Mexican lime (Citrus aurantifolia (Christm.) Swing.), CVds on etrog citron (C. medica L. cv. Arizona 861-S-1), cachexia on cv. Parson's Special mandarin (C. reticulata Blanco), psorosis on sweet orange (C. sinensis (L.) Osb. cv. Madam Vinous), impietratura on sour orange $(C$. aurantium L.), and tatter leaf on cv. Troyer citrange $(P$. trifoliata (L.) Raf. $\times C$. sinensis (L.) Osb.) (32). The indicators for each disease were bud inoculated and kept at the required temperature in the greenhouse.

Biochemical indexing. Enzyme-linked immunosorbent assay (ELISA) was employed to establish the presence of CTV. For CVds, total nucleic acids were extracted from shoot tissue of etrog citrons inoculated with the different sources. Young bark and leaf midrib tissue $(2 \mathrm{~g})$ was ground in liquid nitrogen and the nucleic acids extracted by phenol and lithium chloride partitioning $(16,35)$. The samples were analyzed by SPAGE (31) followed by silver nitrate staining (26).

Citrus tristeza virus severity. General host responses. CTV is endemic in South Africa and ELISA confirmed the presence of the virus; however, the severity of the CTV isolates was unknown. Different hosts were bud inoculated with the isolates to establish severity by a general host response as well as the presence of the seedling yellows component of CTV. Bud transfers were preferred to aphid transmissions because of the risk of the aphids transferring only part of the complex.

The CTV isolates were compared to known mild and severe CTV isolates on five different hosts: Mexican lime (C. au- 
rantifolia (Christm.) Swing.), Marsh grapefruit (C. paradisi Macf.), sour orange $(C$. aurantium L.), cv. Madam Vinous sweet orange (C. sinensis (L.), Osb.) and sweet orange on sour orange rootstock (19). After inoculation of the various indicator plants, they were kept at 24 to $28^{\circ} \mathrm{C}$ in an insect-free glasshouse. Growth of the plants were measured after 6 months.

Stem pitting and seedling yellows. In the former CTV test, the standard mild and severe CTV isolates were from grapefruit and were without the seedling yellows (SY) component of CTV (27). A positive reaction for the presence of SY was observed on the grapefruit and sour orange hosts and it was then necessary to compare the SY with CTV isolates known to carry SY. Therefore, they were compared with known mild and severe CTV isolates derived from grapefruit (GFMS 12 and GFSS 1, both without SY), lime (LMS 6, with mild SY), and sweet orange (SM 34, mild SY; SM 42, moderate SY; SOSS 2, severe SY). CTV isolates GFMS 12 and LMS 6 are presently being used as pre-immunizing agents in the Southern Africa Citrus Improvement Program $(38,42)$. The isolates were inoculated into a stem pitting (SP)-sensitive host, Mexican lime, and a SY-sensitive host, sour orange, by budding. The plants were kept at 20 to $24^{\circ} \mathrm{C}$, which favors the virus, and a larger impact on the indicator plants was expected at this temperature than in the previous experiment. Growth, SP, and SY were assessed 6 months after inoculation.

When this trial was initiated, etrog citron plants that were inoculated with isolate CD 8 displayed severe symptoms of viroid infection, and it was decided to exclude this isolate in further glasshouse investigations.

Temperature sensitivity. Isolates CD 4, CD 9, and CD 10 were compared with two known citrus viroid isolates, CD 11 (citrus exocortis viroid; CEV) and CD 12 (GroupIII citrus viroid; CVd-III) by bud inoculating etrog citron on rough lemon rootstock (40). A total of 10 replications of each isolate were kept at each of three temperature regimes: 20 to $24^{\circ} \mathrm{C}, 24$ to $28^{\circ} \mathrm{C}$, and 28 to $32^{\circ} \mathrm{C}$. After 6 months, growth since inoculation was removed and dried at $60^{\circ} \mathrm{C}$ for $24 \mathrm{~h}$ and the mass determined.

Mechanical transmission. Two known citrus viroid isolates $(\mathrm{CD} 11=\mathrm{CEVd}$ and CD $12=$ CVd-III) and three dwarfing isolates (CD 4, CD 9, and CD 10) were slash inoculated to etrog citron. A budding knife was used to cut into the bark of the donor plant, after which a cut was made into a receptor plant. A total of 10 knife slashes were made from each isolate to a healthy etrog citron; there were six replicates (20). Plants were kept at 20 to $24^{\circ} \mathrm{C}$ for 6 months. At the end of that time, the growth since inoculation was harvested and dried as described above.

\section{RESULTS}

Transmissibility of the dwarfing condition. Isolates CD 4 and CD 9 each reduced canopy volumes by $60 \%$, and $\mathrm{CD}$ 10 by $30 \%$, without any detrimental effects (Table 2). The reduction by CD 10 was not significant. CD 8 , containing a mixture of CEVd and CVd-III, did not affect growth. Production for all treatments was correlated with tree size, and the yield efficiency of the inoculated trees was equal to that of the uninoculated control trees.

External and internal fruit quality was not affected by any of the dwarfing isolates (data not shown).

Identification of transmissible agents. Etrog citron plants inoculated with isolate CD 8 developed severe symptoms typical of CEVd. None of the plants inoculated with the other isolates developed any symptoms on this host. Indicator plants for cachexia, psorosis, impietratura, and tatter leaf remained healthy for all the isolates. No CVds could be detected by sPAGE in isolates CD 4, CD 9, and CD 10. A mixed infection of CEVd and CVd-III was detected in isolate CD 8.

CTV severity. SP in Mexican lime plants with isolate CD 4 was more severe than that of plants with the two pre-immunizing populations GFMS 12 and LMS 6 but less severe than those with the two severe populations (Table 3 ).

Overall, none of the dwarfing isolates were more severe than the known severe CTV isolate (GFSS 1). However, GFSS 1 does not contain the SY component of CTV, and SY symptoms were observed in the grapefruit and sour orange indicators where $\operatorname{CD~4,~CD~9,~and~CD~} 10$ were inoculated. CD 8-infected plants were not significantly different from GFMS 12infected or virus-free plants. CD 4infected plants were also not significantly different from the GFMS 12 plants, but were significantly smaller than the controls.

There was variation in the responses of the indicator plants. The most severe effect was that of isolate CD 10 in the sweet on sour combination.

SP and SY. The SY component of isolate CD 4 was similar in severity to that of LMS 6 (Table 4). Growth and SP development of Mexican lime inoculated with two dwarfing isolates (CD 9 and CD 10) were similar to those of plants inoculated with the two severe CTV isolates GFSS 1 (from grapefruit without SY) and SOSS 2 (from sweet orange with SY). Plants with isolate CD 4 were similar to those with CTV isolate SM 41 from sweet orange, but more severe than sweet orange isolate SM 34, lime isolate LMS 6, and grapefruit isolate GFMS 12.

Temperature influence. The effect of the CVd isolates CD 11 and CD 12 on plants at the different temperatures was opposite to that of the dwarfing isolates (Table 5). At 20 to $24^{\circ} \mathrm{C}$, growth of plants inoculated with the three dwarfing isolates was similar to that of plants inoculated with CEVd. At 24 to $28^{\circ} \mathrm{C}$ and 28 to $32^{\circ} \mathrm{C}$, however, plants inoculated with $\mathrm{CEV}$ were significantly smaller than those inoculated with the dwarfing isolates. Neither dwarfing isolate differed from each other at any temperature regime. Plants with CVd-III were less affected by temperature than those with CEVd. The effect of both viroids increased with higher temperatures; however, not significantly.

Mechanical transmission. Both $\mathrm{CVds}$ were mechanically transmitted by knifeslash inoculation (20) but none of the dwarfing isolates were transmitted (Table 5). Symptoms of viroid infection developed on all the plants that were slash inoculated by the two viroid isolates. Reduction in growth occurred only where the CEVd isolate CD 11 was inoculated. When comparing the plants with the dwarfing isolates, none of the agents which were

Table 2. Tree size, 4-year average production, and production efficiency in last production year of 5-year-old cv. Delta Valencia on cv. Yuma citrange rootstock ${ }^{\mathrm{z}}$

\begin{tabular}{|c|c|c|c|}
\hline Isolate & $\begin{array}{c}\text { Canopy } \\
\text { volume } \\
\left(\mathbf{m}^{3}\right)\end{array}$ & $\begin{array}{l}\text { Production } \\
\text { (kg/tree) }\end{array}$ & $\begin{array}{c}\text { Production } \\
\text { efficiency } \\
\left(\mathrm{kg} / \mathrm{m}^{3}\right)\end{array}$ \\
\hline Control & $5.0 \mathrm{a}$ & $28.2 \mathrm{a}$ & $8.0 \mathrm{NS}$ \\
\hline CD 4 & $1.9 \mathrm{~b}$ & $9.7 \mathrm{~b}$ & $9.3 \mathrm{NS}$ \\
\hline CD 8 & $5.0 \mathrm{a}$ & $27.4 \mathrm{a}$ & $7.7 \mathrm{NS}$ \\
\hline CD 9 & $2.0 \mathrm{~b}$ & $9.6 \mathrm{~b}$ & 7.1 NS \\
\hline CD 10 & $3.7 \mathrm{ab}$ & $16.7 \mathrm{~b}$ & 7.1 NS \\
\hline
\end{tabular}

${ }^{\mathrm{z}}$ Figures followed by the same letter do not differ significantly at the $5 \%$ level (least significant difference); NS = not significant.

Table 1. Origin of isolates derived from symptomless dwarfed citrus trees

\begin{tabular}{llll}
\hline ID number & Location/province & Scion & Rootstock \\
\hline CD 4 & Nelspruit, Mpumalanga & Valencia & Trifoliate \\
CD 8 & Karino, Mpumalanga & Lemon & Rough lemon years old, \pm 2 m high \\
CD 9 & Rustenburg, North West & Navel & Trifoliate \\
CD 10 & Amanzi, Eastern Cape & Valencia & Yuma citrange \\
\hline
\end{tabular}


responsible for the reduction in growth at the bud-inoculated plants were transferred by slashing.

Disease. No bark scaling, gumpocket, or any other disorder relating to viroid infection was observed. Likewise, trees showed no declining symptoms. No pitting was observed after bark was removed across the bud unions which appeared normal, indicating no detrimental effect of CTV.

Huanglongbing (HLB; greening), caused by Liberobacter africanum, is a serious disease threatening citrus production in the cool areas of southern Africa. The disease was first observed 3 years after planting. In 1990 (2 years later), fruit symptoms increased to $100 \%$ in some trees despite attempts to control the disease. The average HLB fruit symptoms for each treatment in that year are presented in Table 6 . The dwarfing trial was terminated during this year and all HLB-infected material was removed by pruning. HLB continued to be monitored in 1991, 1993, and 1996 in the control trees and those with $\mathrm{CD} 4$ (Table 6). Infected branches were removed each winter of every year. The percentage of HLB fruit symptoms was kept at a low level for several years by isolate CD 4 .

\section{DISCUSSION}

CTV appears to be the agent responsible for dwarfing in isolates $\operatorname{CD~4,~CD~9,~and~}$ CD 10. No other agent could be detected in these isolates by biological or biochemical indexing. The more severe effect of isolates CD 4, CD 9, and CD 10 on plants at a low temperature than at high temperatures supports the finding. CTV in South Africa is normally more severe at lower temperatures. No evidence exists in South Africa for the presence of CTV isolates that are more severe at high temperatures, as are found in Australia (6). It was also found that these isolates are less effective as dwarfing isolates in a hot citrus-production area (41). This contradicts the statement by Rabe et al. (30). However, van Vuuren and da Graça (39) found unexplained interactions between cv. Yuma citrange rootstock and different CTV isolates. The CTV severity of isolate CD 4 did not differ from that of the pre-immunizing isolate GFMS 12 , but those of isolates CD 9 and CD 10 were more severe (Table 3).
SP in Mexican lime plants with isolates CD 9 and CD 10 was more severe than in the pre-immunizing population, but equal to sweet orange populations, which have potential for cross protecting sweet orange (unpublished data; Table 4).

The absence of a viroid in isolate CD 10 (Amanzi dwarfing factor) supports the finding of Rabe et al. (30). Cv. Yuma citrange rootstock appears to be tolerant to CVd infection because it did not develop any scaling or other detrimental symptoms where isolate $\operatorname{CD~} 8$, which was found to contain CEVd and CVd-III, was inoculated, which supports the findings of Amir et al. (1). It is not clear why the original trees from which $\mathrm{CD} 4$ and $\mathrm{CD} 9$ were derived were dwarfed, because the sweet orange scions on trifoliate rootstock are usually regarded as tolerant to CTV. How- ever, there may be differences in susceptibility in the different $P$. trifoliata selections. Gmitter (22) reported that $P$. trifoliata possesses a single gene that confers virtual immunity to CTV. Calavan et

Table 6. Percentage of fruit with huanglongbing (greening) symptoms in trees inoculated with different isolates from dwarfed trees during 1990 and the occurrence of the disease in subsequent years

\begin{tabular}{cccccc}
\hline & & \multicolumn{4}{c}{ Isolates } \\
\cline { 2 - 6 } Year & Control & CD 4 & CD 8 & CD 9 & CD 10 \\
\hline 1990 & 4 & 0 & 35 & 29 & 14 \\
1991 & 19 & 2 & $\ldots{ }^{z}$ & $\ldots$ & $\ldots$ \\
1993 & 27 & 1 & $\ldots$ & $\ldots$ & $\ldots$ \\
1996 & 46 & 1 & $\ldots$ & $\ldots$ & $\ldots$ \\
\hline
\end{tabular}

${ }_{\mathrm{z}}$ Trees removed due to high huanglongbing infection.

Table 4. Comparison of dwarfing isolates (CD) with mild (M) and severe (S) Citrus tristeza virus isolates on stem pitting (Mexican lime)- and seedling yellows (Sour orange)-sensitive hosts ${ }^{\mathrm{z}}$

\begin{tabular}{lccccc}
\hline & \multicolumn{2}{c}{ Mexican lime } & & \multicolumn{2}{c}{ Sour orange } \\
\cline { 2 - 3 } \cline { 5 - 6 } Isolate & Growth $(\mathbf{m m})$ & Stem pitting & & Growth $(\mathbf{m m})$ & Seedling yellows \\
\hline Control & $745 \mathrm{a}$ & - & & $772 \mathrm{a}$ & - \\
GFMS 12 (M) & $530 \mathrm{bc}$ & + & & $658 \mathrm{ab}$ & - \\
LMS 6 (M) & $598 \mathrm{~b}$ & + & & $678 \mathrm{ab}$ & + \\
SM 34 (M) & $428 \mathrm{c}$ & + & & $338 \mathrm{c}$ & ++ \\
SM 41 (M) & $143 \mathrm{de}$ & ++ & & $153 \mathrm{de}$ & +++ \\
GFSS 1 (S) & $51 \mathrm{e}$ & +++ & & $346 \mathrm{c}$ & - \\
SOSS 2 (S) & $29 \mathrm{e}$ & +++ & & $41 \mathrm{e}$ & +++ \\
CD 4 & $175 \mathrm{~d}$ & ++ & & $565 \mathrm{~b}$ & + \\
CD 9 & $118 \mathrm{de}$ & +++ & & $332 \mathrm{c}$ & ++ \\
CD 10 & $89 \mathrm{de}$ & +++ & & $225 \mathrm{~cd}$ & ++ \\
\hline
\end{tabular}

${ }^{\mathrm{z}}$ Figures followed by the same letter do not differ significantly at the $5 \%$ level (least significant difference). Symptoms: $-=$ none; $+=$ mild; $++=$ moderate; and $+++=$ severe

Table 5. Effects of dwarfing isolates on the growth (grams of dry mass) of etrog citron plants at three temperature regimes ${ }^{\mathrm{z}}$

\begin{tabular}{|c|c|c|c|c|c|}
\hline \multirow[b]{3}{*}{ Isolate } & \multicolumn{4}{|c|}{ Temperature $\left({ }^{\circ} \mathbf{C}\right)$} & \multirow[b]{3}{*}{ Mean bud inoculation } \\
\hline & \multirow{2}{*}{$\frac{\text { Slash inoculation }}{20-24}$} & \multicolumn{3}{|c|}{ Bud inoculation } & \\
\hline & & $20-24$ & 24-28 & 28-32 & \\
\hline Control & $22.1 \mathrm{a}$ & $30.2 \mathrm{a}$ & $26.2 \mathrm{a}$ & $28.9 \mathrm{a}$ & $28.4 \mathrm{f}$ \\
\hline CD 4 & $22.1 \mathrm{a}$ & $10.0 \mathrm{c}$ & $19.6 \mathrm{ab}$ & $20.0 \mathrm{bc}$ & $16.5 \mathrm{~g}$ \\
\hline CD 9 & $23.7 \mathrm{a}$ & $11.8 \mathrm{bc}$ & $13.8 \mathrm{~b}$ & $26.0 \mathrm{ab}$ & $17.2 \mathrm{~g}$ \\
\hline CD 10 & $24.0 \mathrm{a}$ & $6.9 \mathrm{c}$ & $12.6 \mathrm{~b}$ & $18.8 \mathrm{bc}$ & $12.8 \mathrm{~g}$ \\
\hline CD 11 & $10.4 \mathrm{~b}$ & $5.8 \mathrm{c}$ & $3.8 \mathrm{c}$ & $1.4 \mathrm{~d}$ & $3.7 \mathrm{f}$ \\
\hline CD12 & $20.2 \mathrm{a}$ & $19.9 \mathrm{~b}$ & $13.8 \mathrm{~b}$ & $13.3 \mathrm{c}$ & $15.7 \mathrm{~g}$ \\
\hline Mean & $\ldots$ & 14.1 & 15.0 & 18.1 & NS \\
\hline
\end{tabular}

${ }^{\mathrm{z}}$ Figures followed by the same letter do not differ significantly at the 5\% level (least significant difference). NS = not significant.

Table 3. Effect of dwarfing isolates (CD) on the growth (mm) of Citrus tristeza virus (CTV) indicators in comparison with uninoculated virus-free plants (control) and plants inoculated with known mild (GFMS 12) and severe (GFSS 1) CTV populations ${ }^{\mathrm{z}}$

\begin{tabular}{|c|c|c|c|c|c|c|}
\hline \multirow[b]{2}{*}{ Isolate } & \multicolumn{6}{|c|}{ CTV indicator fruit type } \\
\hline & Mexican lime & Grapefruit & Sour orange & Sweet orange & Sweet/Sour orange & Mean \\
\hline Control & $1,049 \mathrm{a}$ & $435 \mathrm{~b}$ & $698 \mathrm{a}$ & $597 \mathrm{ab}$ & $663 \mathrm{a}$ & $688 \mathrm{a}$ \\
\hline GFMS 12 & 747 bc & $437 \mathrm{~b}$ & $658 \mathrm{a}$ & $470 \mathrm{~b}$ & $648 \mathrm{a}$ & $592 \mathrm{ab}$ \\
\hline GFSS 1 & $142 \mathrm{e}$ & $127 \mathrm{~d}$ & $372 \mathrm{~b}$ & $836 \mathrm{a}$ & $267 \mathrm{~b}$ & $349 \mathrm{~cd}$ \\
\hline CD 4 & $692 c$ & $587 \mathrm{a}$ & $419 a b$ & $534 \mathrm{~b}$ & $299 \mathrm{~b}$ & $506 \mathrm{bc}$ \\
\hline CD 8 & $866 \mathrm{~b}$ & $297 \mathrm{c}$ & 716 a & $569 \mathrm{ab}$ & $547 \mathrm{a}$ & $599 a b$ \\
\hline CD 9 & $321 \mathrm{~d}$ & $297 \mathrm{c}$ & $430 \mathrm{ab}$ & $439 \mathrm{~b}$ & $250 \mathrm{~b}$ & $347 \mathrm{~cd}$ \\
\hline CD 10 & $314 \mathrm{~d}$ & $528 \mathrm{ab}$ & $168 \mathrm{ab}$ & $670 \mathrm{ab}$ & $9 \mathrm{c}$ & $338 \mathrm{~d}$ \\
\hline
\end{tabular}

${ }^{\mathrm{z}}$ Figures followed by the same letter do not differ significantly at the $5 \%$ level (least significant difference). 
al. (10) found Rubidoux trifoliate moderately susceptible to CTV and Grisoni et al. (24) found SP in cv. Pomeroy trifoliate.

A promising result of this research was the reduction in HLB infection where isolate $\mathrm{CD} 4$ was inoculated. This requires further research. A similar result was obtained by $\mathrm{Su}$ (37) where a dwarf strain of CTV was inoculated in grapefruit and pummelo. It was also found by Chen et al. (14) that HLB organisms and CTV particles were rarely present in the same cell. Additional investigations have been initiated to determine the protection potential against HLB, as well as its potential as a CTV cross-protector for sweet orange and mandarin.

\section{ACKNOWLEDGMENTS}

We thank B. Q. Manicom for his enthusiasm and support on this research and J. B. van der Vyver for assistance.

\section{LITERATURE CITED}

1. Amir, A., Ashkenazi, S., Shaked, A., and Kahn, M. 1988. Exocortis dwarfed trees in Ysreel Valley, Israel. Proc. Int. Soc. Citriculture 2:913-915.

2. Anonymous, 1990. Exporters Packing Guide. Outspan International, P.O. Box 7733, Hennopsmeer, South Africa.

3. Aubert, B. 1990. High density planting of Jiaogan mandarin in the lowland area of Shantou and implications for greening control. Pages 149-157. In: Proc. Asia Pac. Int. Conf. Citriculture. Chiang Mai, Thailand.

4. Bacon, P. E. 1980. Effects of dwarfing inoculations on the growth and productivity of 'Valencia' oranges. J. Hortic. Sci. 55:49-55.

5. Boswell, S. B., McCarty, C. D., Hench, K. W., and Lewis, L. N. 1975. Effect of tree density on the first ten years of growth and production of 'Washington' navel orange trees. J. Amer. Soc. Hortic. Sci. 100:370-373.

6. Broadbent, P. 1991. Outbreak of orange stem pitting in Queensland. Aust. Citrus News 67:7-10.

7. Broadbent, P., Forsyth, J. B., Hutton, R. J., and Bevington, K. B. 1992. Guidelines for the commercial use of graft-transmissible dwarfing in Australia-potential benefits and risks. Proc. Int. Soc. Citriculture 2:697-701.

8. Broadbent, P., Fraser, L. R., and Long, J. K. 1971. Exocortis in dwarfed citrus trees. Plant Dis. Rep. 55:998-999.

9. Burger, W. P., Vincent, A. P., Barnard, C. J., Du Plessis, J. A., and Smith, J. H. E. 1970. Metodes waarvolgens die grootte van sitrusbome bepaal kan word. S. Afr. Citrus J. 433:13-15.

10. Calavan, E. C., Blue, R. L., Burns, R. M., and Lee, B. W. 1974. Experimentally induced, long-term effects of tristeza virus on trees of Valencia orange on citrange, Red rough lemon, and trifoliate orange rootstocks near the California coast. Pages 94-96 in: Proc. Sixth Conf. Intern. Org. Citrus Virol. L. G. Weathers and M. Cohen, eds. University of California, Riverside.

11. Cartia, G., La Rosa, R., and Catara, A. 1984. A gummy pitting of trifoliate orange in Italy. Pages 184-187 in: Proc. Ninth Conf. Intern. Org. Citrus Virol. S. M. Garnsey, L. W. Timmer, and J. A. Dodds, eds. University of California, Riverside.

12. Castle, W. S., Pelosi, R. R., and Lee, R. F. 1991. Growth and yield of young sweet orange trees on Swingle citrumelo rootstock in- oculated with viroids. Pages 214-218 in: Proc. Eleventh Conf. Intern. Org. Citrus Virol. R. H. Brlansky, R. F. Lee, and L. W. Timmer, eds. University of California, Riverside.

13. Castle, W. S., and Phillips, R. L. 1980. Performance of 'Marsh' grapefruit and 'Valencia' orange trees on eighteen rootstocks in a closely spaced planting. J. Am. Soc. Hortic. Sci. 105:496-499.

14. Chen, M., Miyakawa, T., and Matsui, C. 1972. Simultaneous infection of citrus leaves with tristeza virus and mycoplasma-like organisms. Phytopathology 62:663-666.

15. Cohen, M., Castle, W. S., Phillips, R. L., and Gonsalves, D. 1980. Effect of exocortis viroid on citrus tree size and yield in Florida. Pages 195-200 in: Proc. Eighth Conf. Intern. Org. Citrus Virol. E. C. Calavan, S. M. Garnsey, and L. W. Timmer, eds. University of California, Riverside.

16. Duran-Vila N, Flores R. and Semancik, J. S. 1986. Characterization of viroid-like RNAs associated with the citrus exocortis syndrome. Virology 150:75-84.

17. Fraser, L. R., and Broadbent, P. 1980. Variation in symptom expression and gummy pitting in citrus trees on Poncirus trifoliata rootstock in New South Wales. Pages 201-208 in: Proc. Eighth Conf. Intern. Org. Citrus Virol. E. C. Calavan, S. M. Garnsey, and L. W. Timmer, eds. University of California, Riverside.

18. Fraser, L. R., and Levitt, E. C. 1959. Recent advances in the study of exocortis (scaly butt) in Australia. Pages 129-133 in: Citrus Virus Diseases. J. M. Wallace, ed. University of California, Riverside.

19. Garnsey, S. M., Gumpf, D. J., Roistacher, C. N., Civerolo, E. L., Lee, R. F., Yokomi, R. K., and Bar-Joseph, M. 1987. Toward a standardized evaluation of the biological properties of citrus tristeza virus. Phytophylactica 19:151-157.

20. Garnsey, S. M., and Jones, J. W. 1967. Mechanical transmission of exocortis virus with contaminated budding tools. Plant Dis. Rep. 51:410-413.

21. Gillings, M. R., Broadbent, P., Gollnow, B. I., and Lakeland, C. 1988. Viroids in Australian citrus. Proc. Int. Conf. Citriculture 2:881-895.

22. Gmitter, F., Jr. 1996. The use genetic markers for rootstock breeding. Proc. Int. Soc. Citriculture 2:1251-1252.

23. Golomb, A. 1988. High density plantings of intensive groves: a challenge and realization. Proc. Int. Soc. Citriculture 2:921-930.

24. Grisoni, M., Sporrer, F., and Aubert, B. 1991. Behaviour of 14 rootstocks inoculated with a severe strain of citrus tristeza virus in Reunion Island. Pages 171-177 in: Proc. Eleventh Conf. Int. Org. Citrus Virol. R. H. Brlansky, R. F. Lee, and L. W. Timmer, eds. IOCV, Riverside, CA.

25. Hadas, R., Bar-Joseph, M., and Semancik, J. S. 1989. Segregation of a viroid complex from a graft-transmissible dwarfing agent source for grapefruit trees. Ann. Appl. Biol. 115:515-520.

26. Igloi, G. L. 1983. Silver stain for the detection of nanogram amounts of tRNA following twodimensional electrophoresis. Anal. Biochem. 134:184-188

27. McClean, A. P. D., and van der Plank, J. E. 1955. The role of seedling yellows and stem pitting in tristeza of citrus. Phytopathology 45:222-224.

28. Nauer, E. M., Roistacher, C. N., Calavan, E. C., and Carson, T. L. 1988. The effect of citrus exocortis viroid and related mild citrus viroids on field performance of Washington navel orange on two rootstocks. Pages 204-210 in: Proc. 10th Conf. Intern. Org. Citrus Virol. L. W. Timmer, S. M. Garnsey, and L. Navarro, eds. IOCV, Riverside, CA.

29. Pérez, R., Rodríquez, R., Gonzáles, A., Del Valle, N., and Durán-Vila, N. 1992. Dwarf citrus trees for high density plantings. Proc. Int Soc. Citriculture 2:712-713.

30. Rabe, E., Cook, N., Jacobs, G., and van der Walt, H. P. 1992. Current status of research on citrus tree size control in South Africa. Proc. Int. Soc. Citriculture 2:714-720.

31. Rivera-Bustamante R. F., Gin, R., and Semancik, J. S. 1986. Enhanced resolution of circular and linear molecular forms of viroid and viroid-like RNA by electrophoresis in a discontinuous-pH system. Anal. Biochem. 156:91-95.

32. Roistacher, C. N. 1991. Pages 5-6 in: GraftTransmissible Diseases of Citrus: Handbook for Detection and Diagnosis. FAO of the UN, Rome.

33. Roistacher, C. N., Bash, J. A., and Semancik, J. S. 1993. Distinct disease symptoms in Poncirus trifoliata induced by three citrus viroids from three specific groups. Pages 173-179 in: Proc. Twelfth Conf. Intern. Org. Citrus Virol. P. Moreno, J. V. da Graça, and L. W. Timmer, eds. IOCV, Riverside, CA.

34. Roistacher, C. N., Pehrson, J. E. and Semancik, J. S. 1991. Effect of citrus viroids and the influence of rootstocks on field performance of navel orange. Pages 234-239 in: Proc. Eleventh Conf. Intern. Org. Citrus Virol. R. H Brlansky, R. F. Lee, and L. W. Timmer, eds. IOCV, Riverside, CA

35. Semancik J. S., Morris, T. J., Weathers, L. G., Rordorf, F., and Kearns, D. R. 1975. Physical properties of the minimal infectious RNA from exocortis disease. Virology 63:160-167.

36. Semancik, J. S., Rakowski, A. G., Bash, J. A., and Gumpf, D. J. 1997. Application of viroids selected for dwarfing citrus. J. Hortic. Sci. 72:563-570.

37. Su, H. J. 1981. A tristeza virus strain causing dwarf of pummelo and grapefruit. Proc. Int. Soc. Citriculture 1:423-425.

38. van Vuuren, S. P., Collins, R. P., and da Graça, J. V. 1993. Growth and production of lime trees pre-immunized with mild citrus tristeza virus isolates. Phytophylactica 25:3942.

39. van Vuuren, S. P., and da Graça, J. V. 1996. Effects of citrus tristeza virus isolates and a citrus viroid isolate on growth and production of Delta Valencia on Yuma citrange rootstock Pages 157-161 in: Proc. Thirteenth Conf. Int. Org. Citrus Virol. P. Moreno, J. V. da Graça, and R. K. Yokomi, eds. IOCV, Riverside, CA.

40. van Vuuren, S. P., and da Graça, J. V. 1996. Response of Valencia trees on different rootstocks to two citrus viroid isolates. Proc. Int. Soc. Citriculture 2:705-710.

41. van Vuuren, S. P., and da Graça, J. V. 1996. Application of transmissible agents to control tree size of sweet orange. Proc. Int. Soc. Citriculture 2:711-717.

42. Von Broemsen, L. A., and Lee, A. T. C. 1988. South Africa's citrus improvement programme. Pages 407-416 in: Proc. Tenth Conf Intern. Org. Citrus Virologists. L. W. Timmer, S. M. Garnsey, and L. Navarro, eds. IOCV, Riverside, CA.

43. Wheaton, T. A., Castle, W. S., Tucker, D. P. H., and Whitney, J. D. 1978. Higher density plantings for Florida citrus-concepts. Proc. Fla. State Hortic. Soc. 91:27-33.

44. Whitney, J. D., Wheaton, T. A., Castle, W. S., and Tucker, D. P. H. 1995. Tree height, fruit size, and fruit yield affect manual orange harvesting rates. Proc. Fla. State Hortic. Soc. 108:112-118 